\title{
Ethnopolitical processes as determinants of ethnopolitical management in Eastern European countries in the context of sub-regional security
}

\section{Introduction}

The last decade of the 20th century, and the first twenty years of the 21 st century, bore witness to many political, social and economic changes in Eastern Europe. The fall of the bipolar world order triggered political and economic transformations in the Republic of Belarus, Republic of Moldova and Ukraine. The Eastern European subregion, ${ }^{1}$ due to its geographical location and great cultural and ethnic diversity, became a sphere of influence of two opposing forces: the Russian Federation and the European Union. Hence, the area is particularly susceptible to various ethnopolitical processes and confrontations, some of them turning into conflicts that threaten its security. The ongoing political and economic transformation of the countries under study, with all its pathologies and corruption, as well the outbreak of the war in Donbas in 2015, with federalization of Ukraine as one of possible solutions, or the 'frozen conflict' in Transnistria - all these prove that the current regimes generate one crisis after another. Their very nature prevented them from developing effective mechanisms to monitor and control ethnopolitical processes, or to find solutions to ethnopolitical conflicts (especially in Ukraine and the Republic of Moldova), which has a substantial negative influence on the sub-regional security. In all of the above-mentioned countries, we can observe the emergence or development of ethnopolitical processes. In addition, ethnonationalist and separatist forces come into play, as in case of the war in Donbas and the establishment of Luhansk and Donetsk People's Republics. In practice, such

${ }^{1}$ Usually, Eastern European countries are defined as those countries that are either entirely or for the most part located in the Eastern European Plain. The region comprises Baltic states (Lithuania, Latvia and Estonia), Eastern Slavic countries (the Russian Federation, Ukraine and the Republic of Belarus) and the Republic of Moldova. In addition, the countries under study (the Republic of Belarus, the Republic of Moldova and Ukraine) are considered a part of the so-called Central and Eastern Europe - an area marked out by geopolitics and international relations that, in the broadest definition, includes: 1) the Visegrad Group (Poland, the Czech Republic, Slovakia and Hungary); 2) Baltic states (Lithuania, Latvia and Estonia); 3) the Republic of Belarus, Ukraine and the Republic of Moldova; 4) countries formed after the breakup of Yugoslavia (Slovenia, Croatia, Bosnia and Herzegovina, Montenegro, Macedonia, Serbia and Kosovo); 5) other Balkan countries (Albania, Bulgaria and Romania) (Baluk, 2016, p. 12-13; Lach, 2014, p. 35). According to UN (the United Nations Statistics Division) classification, Eastern Europe includes the following countries: the Republic of Belarus, Bulgaria, the Czech Republic, the Republic of Moldova, Poland, Romania, Russia, Slovakia, Ukraine and Hungary (Standard, 2019). 
ambitions can result in the change of state borders and further escalation of the security crisis in that post-Soviet area. Advanced transformational processes occurring in post-Soviet countries show that adaptation of multinational societies to the new reality is not easy and presents a challenge both to domestic politics of individual countries, including ethnopolitics and its management, and to foreign politics that affects international relations in the region (Freedom, 2019). The analysis of literature concerning ethnopolitical determinants, subjects, concepts and solutions in Eastern European countries (Bodio, Marszałek-Kawa, 2018; Kelley, 2004; Hale, 2008; Zisserman-Brodsky, 2003) reveals the need for research into ethnopolitical management and connections between ethnopolitics and national security of individual countries. However, the dynamic nature of the issues under study, as well as the lack of access to relevant data, make it difficult to provide complimentary forecasts that would take into account the fact that determinants of ethnopolitical management in individual countries, including those connected with ethnopolitical processes and their impact on the sub-regional security, can evolve.

The article is aimed at the analysis of ethnopolitical processes (as determinants in ethnopolitical management) that affect the safety of Eastern European countries. The scope of research covers the independent Republic of Belarus, Republic of Moldova and Ukraine in both geographical and temporal terms. The author asks the following 3 questions: 1) Are national and ethnic minorities in Eastern European countries represented in state power structures? 2) Do national and ethnic minorities in Eastern European countries take actions as political parties and organizations? 3) Do the presence and activity of minorities in state authorities, political parties and organizations affect the national security in the countries of the sub-region?

The study adopts a multidisciplinary approach, combining methodologies characteristic for management sciences, politics, international relations and security sciences. The author also referred to the results of her own research conducted abroad in the period 2014-2018, as well as in-depth interviews she carried out between 2016 and 2018 at the academic centre of the University of Social Sciences in Warsaw.

\section{Politicization of ethnicity in relation to national security}

A key aspect in discussion on ethnopolitical processes in Eastern European countries is politicization of ethnicity. According to J. Rotschild, it is a dialectic process that is supposed to make an ethnic community stronger by emphasizing its distinctiveness and facilitating its adaptation to the ever-changing political environment. It allows a member of a specific community to identify with its objectives and demands (Rotschild, 1981, p. 6). It can also promote (or act against) national integration, legitimize (or question) the current political system and either strengthen or weaken the authorities. Politicization of ethnicity is defined by the following characteristics: 1) making an ethnic group aware of the possibilities of using political mechanisms and institutions to preserve their values and ethnic culture; 2) sparking the group's interest in their own distinctiveness; 3) mobilization of ethnicity; 4) controlling the political behaviour of an ethnic group. Indeed, the noticeable politicization of ethnicity in East- 
ern European countries triggered mechanisms of ethnic mobilization that are characterized with their ethnocultural and ethnopolitical aspects and concern both titular and non-titular population. This makes the process of establishing the state and national identities even more complex. Ethnic mobilization involves organized groups that are bound together by shared values associated with their ethnic identity (including skin colour, language, customs, etc.) and pursue common goals (Olzak, 1991, p. 355). It reveals collective goals of a specific community that tries to spur and maintain its social, political and cultural activity, while simultaneously rejecting the current social order, and consequently accepting the social and political changes, introduced as a result of its own actions and concerning the way it is perceived by other ethnic groups.

When exploring the issue of politicization of ethnicity in Eastern European countries, we eventually arrive at a conclusion that it is the driving force behind ethnicization of the system of government "that can be perceived as a sort of ethnic appropriation of the state by the demographically and politically dominating titular nation" (Wierzbicki, KarolakMichalska, 2016, p. 204). It should be added that in the nineties of the 20th century, Eastern European countries focused on safeguarding the interests of titular nations, which provoked defensive reactions of non-titular population that used their own ethnopolitical and ethnocultural organizations to make their voice heard.

In fact, such politicization and ethnic mobilization might produce various effects - both positive (e.g. reaching the goals set by individual groups) and negative. Negative consequences often include ethnic or ethnopolitical conflicts resulting from mobilization and antagonization of political elites of various ethnic groups. Researchers investigating the phenomenon of ethnic or ethnopolitical conflict adopt various approaches. For example, according to R. Zenderowski and J. Pieńkowski, ethnic conflict is a social process occurring between individuals or ethnopolitical organisms. It originates from conflicting goals and interests and provokes hostility between ethnic groups (Zenderowski, Pieńkowski, 2014, p. 156). It also affects the local and national security and can potentially pose a threat to international safety (Jakubowski, 2018, p. 6-7). Ethnopolitical conflict, on the other hand, is of internal character and concerns the access to political goods, such as power, the right to territorial autonomy, independence (separatism) or incorporation into another country (irredentism). The parties to the conflict use ethnicity-based argumentation. In the Republic of Moldova, an ethnopolitical issue that presents a serious challenge is Gagauzian and Transnistrian separatism, while Ukraine has to deal with separatists in Donbas (Luhansk and Donetsk People's Republics). Donbas and separatist Transnistria are areas that can hardly be defined as internally integral in ethnic terms.

\section{National and ethnic minorities in power structures of Eastern European states}

The activity of representatives of national and ethnic minorities in power structures is connected with the phenomenon of ethnicization, which manifests itself through ethnocracy, i.e. recruitment of political elites and public administration staff from among titular nationals. Ethnocracy presents an obstacle to active citizenship, including public political participation. If we consider factors that promote ethnocracy, the 
subject literature suggests that "[...] it is possible in countries that, in general, see much competition between ethnic communities as regards access to power and influence on the authorities" (Wierzbicki, Karolak-Michalska 2016, p. 244). Thus, we can hazard a guess that, in the sub-region under study, ethnocracy is particularly noticeable: 1) in the multi-ethnic Republic of Moldova, mainly between Moldovans, Romanians and Russians who compete for access to and influence on power structures; 2) in Ukraine, where the Russians demand that Russian be declared an official language. Representation of national and ethnic minorities in state authorities of the Republic of Belarus, Republic of Moldova and Ukraine is the outcome of many different factors, including ethnodemographic, legal and political (e.g. limited number of seats for the minorities in parliament, assignment of posts in state organs, taking into account the minorities' interests in individual government departments, actions encouraging minority representatives to seek employment in state agencies, guaranteeing minorities' participation in the election system, political activity of the minorities and transformation of the political system), as well as demographic and social (demographic potential of the titular nation that fills the top-level positions in state organs, public institutions and offices, obligation to declare one's nationality when applying for a position in state structures, and requirement for state representatives to speak an official language).

The analysis of main factors that determine representation of national and ethnic minorities in state bodies in the countries of the sub-region leads to a conclusion that, in the period 1991-2019, power structures in the discussed countries were dominated by titular nations (i.e. Ukrainians, Belarussians and Moldovans, respectively), even though none of those countries impose any restrictions on national or ethnic groups as regards their share in power. Despite the fact that minority representatives are allowed to participate in the state-building processes, Belarussians, Moldovans and Ukrainians are actually guaranteed privileged positions in state agencies in their respective countries, as no vacancies are 'reserved' for the minorities, while titular nations are elevated to the top of the official hierarchy. The countries in the discussed sub-region adopted hybrid models, based on simultaneous control and acceptance of diversity. Power-enforcement structures (police and the military), as well the judiciary system, are virtually monopolized by titular nations, which makes it easier for the state authorities to suppress any signs of discontent in other ethnic groups. However, none of the investigated countries developed any organized system of discrimination to maintain the inferior position of the minorities. In 1991-2019, no practical steps to increase participation of individual minorities in power structures were taken by the authorities in the countries of the sub-region.

Research into the issue of representation of national and ethnic minorities in the legislative of Eastern European countries in the period 1991-2019 is not a small challenge (the lack of comprehensive data makes it impossible to carry out a detailed analysis). In the Republic of Belarus, the only minority with Prazauskas' coefficient $(\mathrm{PC})^{2}$ higher

${ }^{2}$ Quotient of the percentage participation in power and percentage share in general population. When the coefficient value is equal to 1 , it means that representation of a specific nation in state and administration bodies is equal to its percentage share in the whole population. Prazauskas' coefficient $>1$ means that the nation in question is overrepresented, when compared to its share in the general population, while the coefficient $<1$ means that the nation is underrepresented. 
than 1, which corresponds to overrepresentation in power structures, are the Russians (in the legislative period 1996-2000, PC was equal to 1.36, in 2000-2008, it was 1.59, and in 2009-2019 it was 2.17). Each of the remaining minorities was underrepresented in the researched period. Similar situation can be observed in the Republic of Moldova, where the Russians also are overrepresented in the legislative structures (in the periods 1990-1998, 1998-2002 and 2003-2019 Prazauskas' coefficient was equal to 1.23, 1 and 2.44, respectively). Russian representatives in the Moldovan parliament call for closer relationship between the Republic of Moldova and the Russian Federation. For example, in 2008, Moldovan parliament, largely thanks to the efforts of the Russian minority, adopted the National Security Strategy that provided for cooperation between Moldova and Russia in the area of national security (The Moldovan, 2008). When discussing representation of minorities in Moldovan parliament structures, we should also not forget about Bulgarians, who were overrepresented in the period between 1990 and 1998 (PC 2). (Recensamant.statistica, 2014). In Ukraine, on the other hand, the only minority that was overrepresented in the legislative, were the Russians, in the period between 1990 and 1994 (PC 1.01). In later years, Russians were underrepresented in the Ukrainian parliament (Wierzbicki, Karolak-Michalska). For example, in 2007-2009, Russian members of the parliamentary Committee for Human Rights, National Minorities and Inter-Ethnic Relations of Ukraine, co-created 32 legal projects (Legislative, 2009). However, after 2014, their activity was less prominent.

As regards activity of other minorities in parliaments of Eastern European countries, we should also remember about the Hungarian minority in Ukraine. In 2014, Andrea Bocskor, a Hungarian minority activist from the Carpathian Ruthenia region, was elected to the European Parliament from the list of the Fidesz party (Deputies, 2020). Hungarian minority advocates establishment of a single-member district where Hungarians would constitute the majority. This would allow to elect a member of parliament who would represent the Hungarian minority in Verkhovna Rada of Ukraine. In 2012, László Brenzovics, a then-candidate of the Party of Regions, became a Hungarian representative in the Ukrainian parliament. He was then re-elected in 2015, this time from the list of Petro Poroshenko Bloc (Groszkowski, Iwański, Sadecki, Dąborowski, 2017, p. 29).

When discussing representation of minorities in state power structures in the Eastern European sub-region, we should not forget about the executive. In 1991-2019, executive bodies of the countries under investigation were dominated by titular nations, mostly owing to ethnodemographic structures of Belarussian, Moldovan and Ukrainian societies. In fact, none of those countries adopted any laws that would prevent a person of different nationality to be appointed a president or a member of parliament. However, a candidate for becoming the head of state is required to speak an official language, which might prove a serious obstacle for the minorities. In the period from 1991 to 2019, in each of the above-mentioned countries, the presidential office was held by a person of titular nationality. The same applied to the majority of prime ministers and deputy prime ministers. In case of the Republic of Belarus and the Republic of Moldova, those functions were performed only by Belarussians and Moldovans, respectively, while in Ukraine, some offices were assumed by the Russians, including prime ministers Vitold Fokin (1990-1992) and Mykola Azarov (who 
was first appointed in 2005 and then held the office from March 2010 to January 28, 2014) (Composition, 2019). The Russians were also entrusted with other functions in executive bodies. In addition, leaders of other minorities were nominated ministers in the Ukrainian government, e.g. Georgian D. V. Žvaniâ in 2005, who became the minister for emergency situations and protection of civilian population against the consequences of the Chernobyl disaster (Composition, 2019). The analysis of executive structures in the countries of the discussed sub-region reveals that in the Republic of Belarus and Ukraine representation of minorities was only marginal, but in the Republic of Moldova Romanian and Bulgarian minorities were represented in executive bodies.

The judiciary in the sub-region is dominated by the representatives of the titular nation. The current law does not include any regulations that would significantly limit the access to this branch of government by minority representatives. Restrictions arise from the specific nature of this line of work, including years of experience and the legal expertise. Apart from the requirements to speak the state language, there are no other provisions of ethnic nature. The number of minority representatives in judicial bodies in the countries of the sub-region is hard to estimate, as the data is not publicly disclosed. The judges' biographical details, published on websites of relevant institutions (including the Constitutional Court of Ukraine), do not include any information about their nationalities. This does not mean, however, that minorities have no representatives in the judicature.

Another interesting issue is representation of minorities in self-government structures of Eastern European countries. Factors determining the presence of minorities in local governments in the countries of the sub-region include: 1) uneven distribution of minorities in those countries (dispersed versus concentrated population); 2) the electoral law - potential restrictions concerning the nationality of candidates for positions in local government structures (no such restrictions were implemented in the analysed countries); 3) imposing a limit on the number of positions in the local authorities that are available to the minorities (no such limits were established in the analysed countries); 4) political activity of individual minorities in their respective districts; 5) personnel policies (no provisions of Belarussian, Moldovan and Ukrainian laws stand in the way of employing non-titular nationals); 6) the requirement to speak an official language that might prove an obstacle for some candidates; 7) the level of satisfaction of individual minorities with their legal status in specific countries.

The special role of minority representatives in self-government units in the countries of the discussed sub-region can be noticed in two cases. The first one concerns the Republic of Moldova, more precisely the Autonomous Territorial Unit of Gagauzia - an area dominated by the Gagauzian minority, who, in 2004, made up $82.6 \%$ of the local population (the data was confirmed by the 2014 census) (Recensamant.statistica, 2014). Accordingly, most offices in that autonomous region are held by Gagauzians. The second case concerns Ukraine and the Autonomous Republic of Crimea. In 1991, the Russians were overrepresented in the local power structures (with Prazauskas coefficient of 1.07/1.03). Similar situation could be observed in Kherson, Dnipropetrovsk, Mykolaiv and Sumy Oblasts. Before 2014 (i.e. prior to incorporation of Crimea into Russia), the Russians maintained their domination in all of the above-mentioned areas, 
except for the Sumy Oblast. As regards Luhansk and Donetsk Oblasts - two provinces with the greatest concentration of Russian population - the outbreak of the war in Donbas made further research impossible (Prazauskas coefficient was equal to 0.57 in 1991, and 0.52 in 2014; population share was $43.6 \%$ in 1991, and $38.2 \%$ in 2014; percentage of self-government positions held by the Russians was $25-40 \%$ in 1991 , and $20-30 \%$ in 2014) (Wierzbicki, Karolak-Michalska, 2016, p. 257). We should also not forget about the Hungarian minority in Ukrainian self-government structures. The Hungarians enjoyed a considerable success in local elections (in October 2015) - as many as 8 Hungarian representatives were appointed members of the 64-person Oblast Council of Carpathian Ruthenia.

To conclude, ethnic proportions in legislative, executive and judicial branches of government in the discussed countries create favourable conditions for Belarussians, Moldovans and Ukrainians, thus revealing the ethnocratic character of their respective political systems. Hence, when it comes to representation of individual minorities in public authorities, state- and nation-building processes tend to cause tension in interethnic relations, which presents a threat to the national security.

\section{Activity of national and ethnic minorities in political parties and organizations}

Political involvement of minorities in the countries of the sub-region varies and some ethnic groups are more committed to act on their own behalf than others. The minorities' willingness to participate in politics might depend on internal conditions in the countries they live in, including such aspects as the size of a minority population and its distribution within the country. They also depend on relations between the majority (usually the titular nation) and the minority, resulting from past and current events, as well as institutional and legal measures that can or cannot be taken to influence political decisions at both central and local level, including implementation of special legal regulations concerning citizens of different ethnic or national background. In addition, predispositions to political activity can depend on: 1) support provided by parent states (e.g. financial support); 2) the minority's attitude to its country of origin; 3) the minority's attitude to the national culture of their historic homeland; 4) the possibility of joining and cooperating with international minority organizations. The author's research into the situation in Eastern European countries in the period from 1991 to 2019 reveals that such factors as development of minority cultures and the need to safeguard the communities' interests still prove to be major determinants that spur minority members into action and motivate them to establish political parties and non-governmental organizations. To these we should add ambition and desire to establish a strong position (as a minority) in relations with titular nations and other ethnic groups, as well as efforts aimed at exerting more influence on other spheres of life. In addition, activity of the minorities is fuelled by resistance (e.g. by state authorities, who can reject specific demands of ethnic groups) that their representatives meet with when they try to put their plans into effect, especially that the opposing group often holds a superior position in power structures and has a decisive voice in ethnic relationships. 
Research into the activity of political parties representing interests of the minorities in Eastern European countries in the period between 1991 and 2019 shows that those parties usually adopt either an internationalist approach (e.g. the Slavic National Patriotic Alliance in Ukraine and the Party of Regions of Moldova) or an ethnic approach (e.g. the "Belaya Rus" Slavic Movement in the Republic of Belarus and the "Russian Bloc" Party in Ukraine). Such parties are characterized with diverse ethnic composition, as their members not always come from the same ethnic background as those they represent, unless required (in 1991-2019, no party in the analysed countries imposed any restrictions of ethnic nature as regards membership or application for specific positions) (Kubaczyk, Majchrzak, Żyła, p. 176). In 1991-2019, political parties representing the minorities in Eastern European countries (e.g. the Belarussian Socialist Assembly (1997), the Party of Regions of Moldova (2011) or the "Russian Block" Party (2001) that represent the interests of Russian minorities in Belarus, Moldova and Ukraine, respectively, or the Hungarian Party in Ukraine) used mostly peaceful methods and focused on educational and informational activity (including public debates).

When analysing political goals of the minorities in the countries of Eastern Europe, we can observe that intra-group political discourse is subject to pluralization. As Eastern European countries undergo social and political transformations, the perspective changes accordingly and more and more ethnocultural and ethnopolitical aspects are brought to light. In addition, the discourse is no longer limited to a single area. On the contrary, it takes on an intrastate and international dimension. It should be emphasized that some minorities are not interested in maintaining their minority status (e.g. the Crimean Russians repeatedly declared they wish to change their social and political position). Thus, programmes of parties representing their interests, despite some undeniable axiological similarities, also reveal their various approaches to political activity. They mostly focus on such issues as development of their national culture, protection of their rights and cooperation with historic homelands (Program of the Party, 2013; Program of the Party Russian, 2013; Information, 2012; Official, 2013; Moldavian, 2012).

A minority that is particularly active in political parties, especially when compared to other countries of the sub-region, are the Russians living in Ukraine (e.g. in 2013, 14 pro-Russian parties cooperated to establish a pro-Russian movement in Ukraine). For example, the Russian Bloc took part in parliamentary elections in 2012 and its leaders (two of them) won mandates in districts where the Russians form the majority (Russian, 2019). When discussing the activity of the minorities in Ukraine, one should not forget about the Hungarians, who have two political parties: the Hungarian Party in Ukraine and the Hungarian Democratic Party in Ukraine. In addition, the Hungarians are represented at all levels of local government in Carpathian Ruthenia.

In 1991-2019, the minorities in Eastern European countries, in an attempt to take an active part in social, political and cultural life, established several non-governmental organizations of various institutional status (e.g. societies) that engage in both formal and non-formal activities. Such minority organizations belong to a broader category of ethnopolitical organisms "encompassing every possible form of organization of social life, along with political institutions, with their legal and political standards, as well as ethnosocial institutions with deep roots in tradition and customs" (Wierzbicki, 2015, 
p. 54). Minority organizations (both ethnosocial and ethnopolitical ones) in the countries of the sub-region are focused on shaping the national or ethnic identities of the minorities to strengthen their bonds with their native cultures and historic homelands. Another important factor in the activity of those organizations is their range of influence. Countrywide organizations focus on the most important problems in the lives of the minorities they represent and cultivate relationships with their motherlands. Regional organizations, on the other hand, define their goals and tasks depending on the local needs. Most importantly, the strength of a minority organization depends on its position in social and political hierarchy of a specific national or ethnic community.

In the Republic of Belarus, minority organizations (mostly those of educational and cultural character, acting locally) have little influence on the country's ethnic politics. As of January 1, 2019, 193 minority organizations are registered in Belarus, 9 of which represent the Azeris, 4 - the Armenians, 3 - the Georgians, 43 - the Jews, 2 - the Kazakhs, 10 - the Lithuanians, 2 - the Germans, 69 - the Poles, 15 - the Russians, and 12 - the Ukrainians (List, 2019). Some of them are recognized in the whole country (e.g. the Union of Belarussian Jewish Social Organizations and Communities), while others are local associations, acting, for example, in one city (such as the "Ruthenia" Minsk Association for Russian Culture).

When looking deeper into the activity of minority organizations in the Republic of Belarus, one cannot fail to notice that the Polish minority is one of the most active ethnic groups in the country. It is represented by the Union of Poles in Belarus, an association of mostly ethnocultural character. For example, in 2019, the Union organized 170 various events and planned many others for 2020 (Union, 2020). In addition, Russian organizations, such as the "Russian Community" Republican Public Association (1994), hold quite influential positions. They work towards ethnocultural goals through organization of cultural events, most of which are aimed at promotion of Russian culture and language, as well festivals promoting cooperation between Belarus and Russia. One should also not forget about the substantial contribution of the Jewish minority. In 1991-2019, the Jews managed to revive the teaching of Hebrew and Yiddish in several Belarussian cities. Thanks to the efforts of the Union of Belarussians Jewish Social Organizations and Communities, numerous scientific conferences concerning the role of Jews in Belarussian history took place. The union also engages in cultural and publishing activity (financed from various sources, including Israeli funds) (Mironowicz, 2015, p. 144). Other minority organisations in Belarus (e.g. the "Lithuanian Community in Belarus" Republican Social Union) focus mostly on protection and preservation of their national culture and language, but, due to small number of members, their initiatives are rather infrequent. In many cases, organizations do not have access to sufficient financial or staff resources, or lack sufficient local support, to effectively press their demands.

In the Republic of Moldova, the number of minority organizations is gradually increasing, starting from 3 in 1989, through 44 in 1998 and 82 in 2010, ending with 102 in 2019 (Bureau, 2020). They engage in various activities. In 2019, 8 Ukrainian minority organizations were registered in Moldova (Bureau, 2020). The most active include the Ukrainian Community in the Republic of Moldova (1994) and the Union of Ukrainians in the Republic of Moldova (1995) that promote Ukrainian culture and 
the teaching of Ukrainian language. They also organize conferences aimed at integration of Ukrainians living in Moldova. The Russian minority also can boast some well-developed organizational structures (in 2019, there were 28 Russian minority organizations in Moldova) (Bureau, 2020). One of the most prominent of them is the Russian Community in the Republic of Moldova (1993). Those organizations are either national (as in the above-mentioned example) or regional (e.g. the Association of Russians in the Rezina District) and focus mostly on protection of Russian rights and promotion of Russian language and culture. They organize festivals, conferences and concerts to integrate the Russian and Russian-speaking population. One should also remember about Bulgarian minority organizations in Moldova (in 2019, there were 6 of them) (Bureau, 2020). The Bulgarian Community in the Republic of Moldova (1995), a countrywide organization, is focused on protection of rights of the Bulgarian minority, including its language and ancestral culture. Another institution that plays a crucial part in Bulgarian integration is the "Bulgarian Centre of Culture" Association (2004). Other minorities with their own organizations in Moldova include the Gagauzians (e.g. the Gagauzian Community in the Republic of Moldova (2008)) and the Jews (e.g. the Jewish Community in the Republic of Moldova (1993)), as well as the Romani, Germans, Lithuanians and Estonians. Their activity takes on an ethnocultural character and their goals include protection of their native culture and language.

In Ukraine, the vast majority of minority organizations represent the Russians - 96 in total, some of which enjoy a national status (e.g. The Russian Community in Ukraine). By way of comparison, the Romanian minority founded 19 organizations (Teres, Jakubowski, 2015, p. 524-525). In 1991-2019, Russian minority organizations were involved in ethnopolitical and ethnocultural activities. For example, the Russian Movement of Ukraine called for making Russian an official language, while the Ukrainian Association of Teachers of Russian Language and Literature advocated protection and development of Russian language and culture (Russian, 2019). The most popular forms of activity are debates, seminars, conferences, preservation of historic monuments and publishing of periodicals. Activity in minority organizations is also characteristic for Hungarians, who are represented by several dozen national organizations acting for the benefit of Hungarian culture. The most important include the Democratic Community of Hungarians in Ukraine and the Association for Hungarian Culture in Carpathian Ruthenia. Their activities can be described as ethnocultural, but they do not refrain from ethnopolitical involvement either. The Hungarians in Carpathian Ruthenia demand that the province be granted cultural autonomy. However, these are not the only minorities that are active in Ukraine. We should also not forget about the Poles (e.g. the Union of Poles in Ukraine), the Moldovans (e.g. the All-Ukrainian Moldovan National and Cultural Association) and the Belarussians (e.g. the "Belarus" Kiev Municipal Association), who focus mostly on ethnocultural activity.

Comparison of goals and tasks of minority organizations in Eastern European countries reveals considerable similarities, even though each of them also displays its own unique characteristics. They engage in various activities, including mobilization of political support or participation in the public debate on ethnic issues. Each of those activities serves different purpose, both in relation to the represented minorities, and 
the entire political system. What all of those minority organizations have in common is their involvement in promotion of their native language and culture, along with protection of their cultural rights and close cooperation with their homelands. The organisations also fight against discrimination of the represented minorities and stand up for their rights (as in case of the Russians and Hungarians in Ukraine or the Gagauzians in the Republic of Moldova).

In the countries of the sub-region, we can observe the emergence of new minority organizations, as well as breakdowns and mergers of the existing ones. In addition, some of them compete with one another for resources (e.g. subsidies) and the right to sole representation of their people. Many such organizations exist only in theory and are unable to actually mobilize their members. Incompetent leadership and the lack of financial support exclude them from active participation in local development processes. In many cases, leaders are incapable of specifying whether their organizations have a progressive or regressive impact on the local community. They are also unable to define what exactly they expect from the state authorities, local governments and their historic homelands. They tend to ignore the local structures, have no idea how to use their human resources and cannot build a coalition.

\section{Conclusions}

National and ethnic minorities that take steps to change their legal status are an integral part of the political landscape in the countries of the Eastern European subregion, especially in the Republic of Moldova and Ukraine. In the period 1991-2019, they tried to realize their political aspirations in various ways. Some actions eventually turned into separatist movements (as in case of the Gagauzians in the Republic of Moldova), while others were aimed at acquiring the status of an official national minority, with all the accompanying rights (as in case of the Russian minority calling for making Russian the second official language of Ukraine), or asserting the minority's cultural autonomy (as in case of the Hungarians in Carpathian Ruthenia). Particular threat to national security is posed by organized separatist actions. In case of the Republic of Belarus, the problem is not observed, but in the Republic of Moldova (Gagauzia, Transnistria) and Ukraine (Donbas, Carpathian Ruthenia) it is a very serious issue. Separatist tendencies of various ethnic groups have a significant impact on the national security policy. In such situations, state authorities have to react to guarantee security and effectively manage ethnopolitical processes in the country. It is recommended that separatist issues should not be 'temporally frozen,' but solved through peaceful means, without compromising the territorial integrity of the countries in question.

Some minority groups, often having their representatives in national power structures, decide to stand up against the central authorities (e.g. the Russians in Crimea), while others are satisfied with institutional solutions, including the right to autonomy (e.g. the Gagauzians in the Republic of Moldova). Thus, to ensure the national security, it is recommended that the minorities use appropriate channels of communication (e.g. consultations with the general public or the competent institutions) to declare 
their needs and expectations as regards the access to resources. They should also be represented in government bodies to be able to defend their interests.

Ethnopolitics in the countries of the sub-region cannot be discussed in isolation from the security policy. Optimal ethnopolitical solutions should be developed in cooperation with the respective ethnic communities. This would provide a valuable insight into the needs of a multi-ethnic society, while the governments would be able to improve their knowledge of ethnopolitical processes occurring in their countries. Taking into account determinants of ethnopolitical management, including representation and activity of minorities in state authorities, political parties and organizations, should have a beneficial influence on ethnopolitics in Eastern Europe, especially in relation to both national and sub-regional security.

\section{Bibliography}

Baluk W. (2016), Images of a New Eastern Europe, "East of Europe”, no. 1, vol. 2, pp. 12-20.

Bureau of Interethnic Relations of the Republic of Moldova. Pages of History (2020), http://www. bri.gov.md, 15.02.2020.

Bodio T., Marszałek-Kawa J. (2018), Politics, Law, Culture and Security in the Post-Soviet Area, Marszałek Publishing House, Torun.

Composition of the Cabinet of Ministers of Ukraine (2019), http://www.kmu.gov.ua, 14.03.2020.

Deputies of the European Parliament (2020), http://www.europarl.europa.eu, 14.03.2020.

Freedom House. Nations in Transit 2018. Raport (2019), http://www.freedomhouse.org/report/nations-transit/2018, 12.02.2020.

Groszkowski J., Iwański T., Sadecki A., Dąborowski T. (2017), A Neighbour Re-discovered. Czech, Slovak and Hungarian relations with Ukraine. The OSW Report, Warsaw, pp. 21-29.

Hale H. E. (2008), The Foundations of Ethnic Politics. Separatism of States and Nations in Eurasia and the World, Cambridge University Press, Cambridge.

Information about Political Parties Registered in the Republic of Belarus (2012), http:// www.minjust.by, 14.02.2020.

Jakubowski A. (2018), The Conditions for Ethno-Political Conflicts, "Central European Political Studies", vol. 1, pp. 5-13.

Kelley J. G. (2004), Ethnic Politics in Europe: the Power of Norms and Incentives, Princeton University Press, Princeton.

Kubaczyk T., Majchrzak A., Żyła M. (2018), National and Ethnic Minorities in the Security Policies of the Central and Eastern Europe Subregion. CIS Countries, AON, Warsaw.

Lach Z. (2014), Analysis of the Level of Socio-Economic Development and Power of the Countries of Central and Eastern Europe, "Geopolitical Review", vol. 9, pp. 31-52.

Legislative Activity in Committees of the Verkhovna Rada of Ukraine (2009), http://www.rada.gov. ua, 14.02.2020.

List of Ethnic Cultural Public Associations Registered in the Republic of Belarus (as of January 1, 2019) (2019), http://www.belarus21.by, 19.02.2020.

Mironowicz E. (2015), Ethnic Policy of Belarus, in: Ethnic Policy of Contemporary Central and Eastern European Countries, eds. H. Chałupczak, R. Zenderowski, W. Baluk, UMCS, Lublin.

Moldavian Ministry of Justice Registered the Party of Regions of Mihail Formuzal (2012), http:// www.regnum.ru, 26.03.2020. 
Olzak S. (1991), Contemporary Ethnic Mobilization, Palgrave Macmillan, London.

Official Website of the Political Party of the Patriot of Moldova (2013), http://www.patriotmd.info, 14.04.2020.

Program of the Party Kievan Rus (2013), http://www.kievskarus.ucoz.ru, 15.03.2020.

Program of the Russian Bloc Party (2013), http://www.rblok.org.ua, 16.03.2020.

Recensamant.statistica 2014 (2014), http://www.recensamant.statistica.md/ru/dissemination/person, 15.08.2019.

Rothschild J. (1981), Ethnopolitics: A Conteptual Framework, Columbia University Press, New York.

Russian Organizations Abroad (2019), http://www.materik.ru, 14.05.2020.

Standard Country or Area Codes for Statistical Use (M49) (2019), http://www.unstats.un.org/unsd/ methodology/m49, 19.03.2020.

Teres N., Jakubowski A. (2015), Ethnic Policy of Ukraine, in: Ethnic Policy of Contemporary Central and Eastern European Countries, eds. H. Chałupczak, R. Zenderowski, W. Baluk, UMCS, Lublin.

The Moldovan Parliament Adopted a New Concept of National Security (2008), http://www.osw. waw.pl, 12.02.2020.

Union of Poles in Belorus (2020), http://www.znadniemna.pl, 17.02.2020.

Wierzbicki A. (2015), Genetic and Cultural Foundations of Ethno-Politics. Ethnonationalist perspective, in: Ethnic Policy. Theories, Concepts, Challenges, eds. H. Chałupczak, R. Zenderowski, E. Pogorzała, T. Browarek, UMCS, Lublin.

Wierzbicki A., Karolak-Michalska M. (2016), Russian Minority in the Ethno-Politics of Eastern Europe and Central Asia, University of Warsaw, Warsaw.

Zdaniuk B. (2016), State Consolidation in the Republic of Moldova, UW, Warsaw.

Zenderowski R., Pieńkowski J. (2014), Nationality Issues in Central and Eastern Europe. Theoretical Issues, UKSW, Warsaw.

Zisserman-Brodsky D. (2003), Constructing Ethnopolitics in the Soviet Union: Samizdat, Deprivation and the Rise of Ethnic Nationalism, Palgrave Macmillan, London.

\section{Summary}

The following article discusses ethnopolitical processes (politicization of ethnicity and ethnopolitical mobilization of national and ethnic minorities) in Eastern European countries. The author analyses social and political activity of national and ethnic minorities, as well as their representation in state authorities of the Republic of Belarus, Republic of Moldova and Ukraine, and concludes that those processes affect the national security of the countries that make up the sub-region. Particular threat to national security is posed by organized separatist actions. In case of the Republic of Belarus, the problem is not observed, but in the Republic of Moldova (Gagauzia, Transnistria) and Ukraine (Donbas, Carpathian Ruthenia) it is a very serious issue. Separatist tendencies of various ethnic groups have a significant impact on the national security policy. They also call for intervention by state authorities, not only in connection with security issues, but also in relation to appropriate management of ethnopolitical processes within the country.

Key words: ethnopolitical processes, ethnic and national minorities, Eastern Europe, security threat, post-Soviet area 


\section{Procesy etnopolityczne jako jedno z uwarunkowań zarządzania etnopolityką w państwach Europy Wschodniej a bezpieczeństwo subregionu}

\section{Streszczenie}

Artykuł przedstawia problematykę procesów etnopolitycznych (polityzacji etniczności, mobilizacji etnopolitycznej mniejszości narodowych i etnicznych) w państwach Europy Wschodniej. Autorka analizując aktywność społeczno-polityczną oraz udział mniejszości narodowych i etnicznych w organach władzy Republiki Białorusi, Republiki Mołdawii, Ukrainy dochodzi do wniosku, że procesy te wpływają na bezpieczeństwo państw subregionu. Szczególne znaczenie dla bezpieczeństwa państw mają te zorganizowane aktywności, które zgłaszają działania separatystyczne. W przypadku Republiki Białorusi problem ten nie występuje, natomiast w Republice Mołdawii (Gagauzja i Naddniestrze) i na Ukrainie (Donbas, Zakarpacie) ma realny wymiar. Tendencje separatystyczne poszczególnych grup etnicznych stanowią istotny element w kształtowaniu polityki bezpieczeństwa państwa. Stają się również przestrzenią, w której konieczna jest reakcja władz państwowych, w tym dotycząca nie tylko bezpieczeństwa, ale także umiejętnego zarządzania procesami etnopolitycznymi w państwie.

Słowa kluczowe: procesy etnopolityczne, mniejszości narodowe i etniczne, Europa Wschodnia, bezpieczeństwo, przestrzeń poradziecka 